\title{
PENGARUH IMPLEMENTASI TOTAL QUALITY \\ MANAGEMENT TERHADAP KINERJA KARYAWAN STUDI PADA PT. BUMI MENARA INTERNUSA SURABAYA
}

\author{
*(Ali Fathoni \\ Fakultas Ekonomi \\ Universitas Islam Lamongan
}

\begin{abstract}
ABSTRAK
Tujuan dari penelitian ini adalah untuk mengetahui pengaruh implementasi TQM terhadap kinerja yang terdiri dari kepemimpinan, perencanaan strategis, fokus pelanggan, informasi dan analisis, manajemen sumberdaya manusia, dan proses manajemen terhadap kinerja karyawan di PT. Bumi Menara Internusa Surabaya. Populasi adalah 540 karyawan dan 270 karyawan sebagai responden. Sampel diperoleh berdasarkan metode simple random sampling, Kedua statistik deskriptif dan Structural Equation Modelling ( SEM ) yang digunakan untuk menguji pengaruh antara variabel. Pengolahan data yang digunakan oleh SPSS dan AMOS 4. Temuan penelitian menunjukkan bahwa : pelaksanaan implementasi TQM yang terdiri dari kepemimpinan, perencanaan strategis, fokus pelanggan, informasi dan analisis, manajemen sumber daya manusia, dan proses manajemen telah secara signifikan dan berpengaruh positif terhadap kinerja karyawan.
\end{abstract}

Kata Kunci : Implementasi TQM, Kinerja Karyawan.

\section{PENDAHULUAN}

Total Quality Management (TQM) adalah sebuah pendekatan dalam meningkatkan kualitas secara sistematis dengan menggunakan banyak dimensi dan telah diaplikasikan secara luas oleh banyak perusahaan dengan tujuan meningkatkan kinerja seperti kualitas, produktivitas dan profi-tabilitas. Dalam berbagai literatur manajemen operasi diketahui bahwa perusahaan diseluruh dunia telah menerapkan TQM selama beberapa dekade terakhir. Disamping itu, telah banyak penelitian dilakukan oleh para pakar yang fokus pada konsep TQM dengan menggunakan atau meninjaunya dari berbagai area atau konteks yang berbeda.

Sejak awal tahun 1980-an TQM telah mendapat perhatian yang besar dari para manajer, karena terbukti mampu meningkatkan kinerja perusahaan. Total Quality Management (TQM) merupakan paradigma baru dalam menjalankan bisnis yang berupaya memaksimumkan daya saing organisasi melalui fokus pada kepuasan konsumen, keterlibatan seluruh karyawan, dan perbaikan secara ber-kesinambungan atas kualitas produk, jasa, manusia, proses dan lingkungan organisasi (Krajewski and Ritzman, 2006). TQM merupakan pendekatan yang seharusnya dilakukan organisasi masa kini untuk memperbaiki kualitas produknya, menekan biaya produksi dan meningkatkan produktivitasnya. Implementasi TQM juga berdampak 
positif terhadap biaya produksi dan terhadap pendapatan (Gaspersz, 2005). Bukti lain juga menunjukkan bahwa perusahaan yang mengejar praktek terbaik TQM dapat mencapai keuntungan yang lebih tinggi dan cashflowsnya sebaik nilai pemegang saham yang lebih besar (Corbett and Rastrick, 2000). Menurut Sila et al. (2007) total quality mana-gement (TQM) memainkan peranan yang sangat penting dalam meningkatkan kekuatan daya saing perusahaan. Di dalam pasar global yang berubah secara terus menerus, disamping pengiriman yang cepat (speed of delivery), kualitas produk juga menjadi salah satu elemen yang penting bagi perusahaan untuk dapat bersaing (competition). TQM adalah salah satu bentuk praktek manajemen terbaik dalam perusahaan yang menekankan paradigma kualitas secara menyeluruh dalam perusahaan.

\section{LANDASAN TEORI}

Secara teoritis, kualitas adalah totalitas bentuk dan karakteristik barang atau jasa yang menunjukkan kemampuannya untuk memuaskan kebutuhan yang tampak jelas maupun tersembunyi (Chase et al., 2005). Beberapa pakar kualitas mendefinisikan kualitas dengan beragam interpretasi. Juran (1989), mendefinisikan kualitas secara sederhana sebagai 'kesesuaian untuk digunakan. Definisi ini mencakup keistimewaan produk yang memenuhi kebutuhan konsumen dan bebas dari defisiensi. Secara factual, kualitas adalah konsep yang cukup sulit untuk dipahami dan disepakati. Dewasa ini kata kualitas mempunyai beragam interpretasi, tidak dapat didefinisikan secara tunggal, dan sangat tergantung pada konteksnya, seperti pada PT. Bumi Menara Internusa Surabaya yaitu perusahaan dibidang perikanan atau terkenal dengan perusahaan pembekuan udang windu.

Heizer and Render (2004) berpendapat bahwa kualitas terutama mempengaruhi perusahaan dalam empat hal, yaitu: (1) biaya dan pangsa pasar: kualitas yang ditingkatkan dapat mengarah kepada peningkat-an pangsa pasar dan penghematan biaya, keduanya juga dapat mempengaruhi profitabilitas; (2) reputasi perusahaan: reputasi perusahaan mengikuti reputasi kualitas yang dihasilkan. Kualitas akan muncul bersamaan dengan persepsi mengenai produk baru perusahaan, praktek-praktek penanganan pegawai, dan hubungannya dengan pemasok; (3) pertanggung-jawaban produk: organisasi memiliki tanggung jawab yang besar atas segala akibat pemakaian barang maupun jasa; dan (4) implikasi internasional: dalam era teknologi, kualitas merupakan fokus perhatian dalam bidang operasional. Apabila produk yang dihasilkan berkualitas, maka akan berimplikasi pada meningkatnya permintaan produk di pasar inter-nasional.

Kualitas telah menjadi salah satu aspek penting dalam persaingan di pasar global. Setiap perusahaan dapat meningkatkan kinerjanya melalui perbaikan berkelanjutan pada aktivitas bisnis yang terfokus pada konsumen, yakni meliputi keseluruhan organisasi dan penekanan pada fleksibilitas dan kualitas. Karena itu, kualitas dan pengelolaannya selalu dikaitkan dengan aktivitas perbaikan berkelanjutan (continous improvement) guna memenangkan persaingan.

Pengukuran kinerja merupakan aktivitas yang paling penting bagi 
manajemen dalam mengelola organisasi perusahaan. Secara umum, kinerja didefinisikan sebagai sejauh mana suatu operasi memenuhi tujuan kinerja, dan langkah-langkah utama dalam rangka memenuhi kebutuhan pelanggan. Fakta menunjukkan bahwa tanpa dilakukan suatu peng-ukuran terhadap kinerja, maka sulit untuk mem-perbaikinya. Oleh karena itu, meningkatkan kinerja organisasi memerlukan identifikasi terhadap variabel-variabel yang mempengaruhi dan mengukurnya dengan akurat. Pengukuran kinerja sangat penting dilakukan bagi suatu organisasi, agar dapat tercapai kinerja bisnis yang optimal (Demirbag et al. 2006).

$$
\text { Brah and Lim }
$$

mengatakan bahwa kinerja perusahaan dapat diukur dalam dua dimensi kinerja yaitu: kinerja operasional dan kinerja organisasi. Kinerja operasional mencerminkan kinerja operasi internal perusahaan dalam hal biaya dan pengurangan pemborosan, meningkatkan kualitas produk, pengembangan produk baru, memperbaiki kinerja pengiriman, dan peningkatan produktivitas. Indikator dan variabel tersebut dianggap sebagai faktor utama karena mereka mengikuti langsung dari tindakan yang diambil dalam kegiatan operasi perusahaan. Sedangkan kinerja organisasi diukur dengan ukuran finansial seperti pertumbuhan pendapatan, laba bersih, rasio laba dengan pendapatan dan laba atas asset, dan non-ukuran finansial seperti investasi dalam $R \& D$, dan kapasitas perusahaan untuk mengembangkan profil kompetitif.

Menurut Zehir and Esin (2009), pengukuran kinerja bisnis dapat dilakukan melalui 2 dimensi yakni: kinerja inovasi dan kinerja karyawan. Kinerja inovasi diukur melalui inovasi produk dibanding pesaing di pasar, jumlah produk baru yang dipasarkan 5 tahun terakhir, dan kecepatan dalam pengenalan produk/jasa baru di pasar. Sedangkan kinerja karyawan diukur melalui 3 indikator yakni tingkat kepuasan karyawan, tingkat kehadiran (absensi), dan moral karyawan.

Studi empiris yang menguji hubungan antara praktik TQM dengan kinerja perusahaan telah banyak dijumpai dalam literatur manajemen operasi. Misalnya Demirbag et al. (2006) melakukan studi empiris untuk mengidentifikasi faktor-faktor penting bagi keberhasilan TQM pada UKM di Turki. Mereka menyimpulkan bahwa ada tujuh critical success factors (CSF) praktik TQM, yaitu data dan pelaporan kualitas, peran manajemen puncak, hubungan kar-yawan, manajemen kualitas pemasok, pelatihan, kebijakan mutu dan manajemen proses. Faktor-faktor Praktik TQM tersebut mampu meningkatkan kinerja perusahaan. Prayogo and Hong (2008) melakukan penelitian pada 130 Industri Manufaktur unit R\&D di Korea. Hasil penelitiannya menemukan bahwa implementasi praktik TQM yang semakin efektif mempunyai pengaruh signifikan terhadap kinerja perusahaan.

Telah banyak dijumpai dalam literatur penelitian yang menghubungkan antara TQM dengan kinerja bisnis. Namun demikian, disisi lain studi yang menghubungkan antara TQM dengan kinerja kar-yawan secara spesifik masih sangat kurang dan relatif masih sedikit. Oleh karena itu penelitian ini secara khusus akan menguji dan menganalisis pengaruh praktik total quality management (TQM) terhadap kinerja karyawan pada PT. Telkom (Tbk.) Cabang 
Makassar.

\section{METODELOGI PENELITIAN Variabel Penelitian dan Pengukurannya}

Adapun jumlah variabel yang akan diuji hubungan dan pengaruhnya dalam penelitian ini terdiri atas 7 (tujuh) variabel yakni: variabel TQM terdiri atas Kepemimpinan (leadership) $\mathrm{X} 1, \quad$ Peren-canaan strategis (strategic planning) $\mathrm{X}_{2}$, Fokus pada pelanggan (customer focus) X3, Informasi dan analisis (information and analysis) $\mathrm{X} 4$, Manajemen sumber daya manusia (people management) $\mathrm{X}_{5}$, dan Manajemen proses (process management) X6 sebagai variabel eksogen (exogenous variable). Sedangkan variabel kinerja karyawan (y) sebagai variabel endogen (endogenous variable).

$$
\text { Variabel total quality }
$$
management (TQM) dalam penelitian ini mengadopsi model yang dikembangkan oleh Prayogo and Brown (2004), dan Prayogo and Dermott (2005). Sedangkan variabel kinerja karyawan diadopsi dari Zehir and Esin (2009). Pengukuran persepsi karyawan terhadap indikator dan variabel dalam penelitian ini menggunakan Skala Likert dengan nilai 1 - 5. Menurut Sugiyono (2008) Skala Likert digunakan untuk mengukur sikap, tanggapan, dan pendapat seseorang mengenai fenomena social

\section{Populasi dan Sampel}

Populasi dalam penelitian ini adalah seluruh karyawan yang bekerja pada PT. Telkom (Tbk.) Cabang Makassar yang berjumlah 540 orang. Penentuan sampel menggunakan teknik acak seder-hana (simple random sampling). Sugiyono (2008) dan Hair et al. (1998) berpendapat bahwa pada teknik sampel random sederhana, apabila subyek penelitian jumlahnya kurang dari 100, lebih baik diambil semua sehingga penelitiannya merupakan penelitian populasi. Selanjutnya jika jumlah subyeknya besar, dapat diambil antara 10-15\%, atau $20-25 \%$ atau lebih. Sehingga jumlah sampel ditetapkan sebanyak 50\% dari jumlah populasi yakni: 270 orang karyawan.

\section{Pengujian Validitas dan Reliabilitas Instrumen}

Validitas mempunyai arti
seberapa besar ketepatan dan kecermatan suatu alat ukur dalam melakukan fungsi ukurnya. Dengan kata lain, suatu tes atau instrumen pengukur dapat dikatakan mempunyai validitas yang tinggi apabila alat tersebut menjalankan fungsi ukurnya atau memberikan hasil ukur yang sesuai dengan maksud dilakukannya pengukuran tersebut. Tinggi rendahnya validitas instrumen menunjukkan sejauh mana data yang terkumpul tidak menyimpang dari gambaran tentang variabel yang dimaksud. Uji validitas dilakukan untuk melihat butir-butir pertanyaan mana yang layak (representative) untuk digunakan mewakili variabel-variabel bebas dalam penelitian. Uji dilakukan dengan menggunakan analisis faktor konfirmatori (confir-matori factor analysis) pada masing-masing variabel laten. Apabila nilai loading factor pada indikator lebih besar dari 0,50 $(\lambda>$ 0,50 ), maka indikator dapat digunakan untuk mengukur variabel atau konstruk (Ferdinand, 2006; Solimun, 2008).

Selain harus valid, instrument juga harus reliable (dapat diandalkan). Uji reliabilitas dimaksudkan untuk 
mengukur tingkat konsistensi instrumen yang digunakan. Dengan demikian instrumen ini dapat dipakai dengan aman karena dapat bekerja dengan baik pada waktu yang berbeda dari kondisi yang berbeda. Jadi reliabilitas menunjukkan seberapa besar pengukuran dapat memberikan hasil yang relatif tidak berbeda bila dilakukan pengukuran kembali terhadap subjek yang sama. Reliabilitas konstruk dinilai dengan menghitung indeks reliabilitas instrumen yang digunakan dari model SEM yang dianalisis. Rumus yang dapat digunakan untuk menghitung reliabilitas konstruk ini adalah sebagai berikut:

$$
\begin{array}{cc} 
& (\Sigma \text { Std. } \\
\text { Coading })^{2} \\
\text { Construct }- \text { Reliability }=\text {--ostd. Loading })^{2} \\
+\Sigma \varepsilon \Phi
\end{array}
$$

Std. Loading diperoleh langsung dari standar-dized loading untuk tiap-tiap indikator yakni nilai lambda $(\lambda)$ yang dihasilkan oleh masing-masing indikator. $\varepsilon \Phi$ adalah measurement error dari tiap-tiap indikator. Measurement error sama dengan 1 - reliabilitas indikator yakni pangkat dua dari standardized loading setiap indikator yang dianalisis. Adapun nilai batas yang digunakan untuk menilai sebuah tingkat reliabilitas yang dapat diterima adalah 0,60 (Ferdinand, 2006; Solimun, 2008). Hasil pengujian terhadap validitas dan reliabilitas instrumen secara lengkap disajikan pada Tabel berikut.
Tabel 1.

\begin{tabular}{|c|c|c|c|c|}
\hline Variabel/ & $\begin{array}{c}\text { Loading } \\
\text { Factor } \\
\end{array}$ & $\lambda^{2}$ & $\begin{array}{c}\text { Kesalahan } \\
\text { Pengukuran } \\
\end{array}$ & \begin{tabular}{|l|} 
Construct \\
Reliability \\
\end{tabular} \\
\hline Indikator & $(\lambda)$ & & $\left(1-\lambda^{2}\right)$ & (CR) \\
\hline $\mathrm{X}_{1.1}$ & 0.670 & 0.449 & 0.551 & \\
\hline $\mathrm{X}_{1.2}$ & 0.701 & 0.491 & 0.509 & \multirow[b]{2}{*}{0.667} \\
\hline $\mathrm{X}_{1.3}$ & 0.522 & 0.272 & 0.728 & \\
\hline Kepemimpinan & 1.893 & 3.583 & 1.787 & \\
\hline$\left(\mathrm{X}_{1}\right)$ & & & & \\
\hline $\mathrm{X}_{2.1}$ & 0.755 & 0.570 & 0.430 & \\
\hline $\mathrm{X}_{2.2}$ & 0.688 & 0.473 & 0.527 & \multirow[b]{2}{*}{0.703} \\
\hline $\mathrm{X}_{2.3}$ & 0.540 & 0.292 & 0.708 & \\
\hline Perencanaan & \multirow{2}{*}{1.983} & \multirow{2}{*}{3.932} & \multirow{2}{*}{1.665} & \\
\hline strategis $\left(\mathrm{X}_{2}\right)$ & & & & \\
\hline $\mathrm{X}_{3.1}$ & 0.662 & 0.438 & 0.562 & \\
\hline $\mathrm{X}_{3.2}$ & 0.712 & 0.507 & 0.493 & \\
\hline$X_{3.3}$ & 0.696 & 0.484 & 0.516 & 0.732 \\
\hline Fokus pada & \multirow[b]{2}{*}{2.070} & \multirow[b]{2}{*}{4.285} & \multirow[b]{2}{*}{1.570} & \\
\hline pelanggan $\left(\mathrm{X}_{3}\right)$ & & & & \\
\hline $\mathrm{X}_{4.1}$ & 0.824 & 0.679 & 0.321 & \\
\hline $\mathrm{X}_{4.2}$ & 0.746 & 0.557 & 0.443 & \multirow[b]{2}{*}{0.851} \\
\hline $\mathrm{X}_{4.3}$ & 0.855 & 0.731 & 0.269 & \\
\hline Informasi dan & \multirow{2}{*}{2.425} & \multirow{2}{*}{5.881} & \multirow{2}{*}{1.033} & \\
\hline analisis $\left(\mathrm{X}_{4}\right)$ & & & & \\
\hline X5.1 & 0.611 & 0.373 & 0.627 & \\
\hline $\mathrm{X}_{5.2}$ & 0.563 & 0.317 & 0.683 & \multirow[b]{2}{*}{0.695} \\
\hline $\mathrm{X} 5.3$ & 0.788 & 0.621 & 0.379 & \\
\hline Manajemen & \multirow{2}{*}{1.962} & \multirow{2}{*}{3.849} & \multirow{2}{*}{1.689} & \\
\hline $\operatorname{SDM}\left(\mathrm{X}_{5}\right)$ & & & & \\
\hline $\mathrm{X}_{6.1}$ & 0.833 & 0.694 & 0.306 & \\
\hline $\mathrm{X}_{6.2}$ & 0.742 & 0.551 & 0.449 & \multirow[b]{2}{*}{0.783} \\
\hline $\mathrm{X}_{6.3}$ & 0.633 & 0.401 & 0.599 & \\
\hline Manajemen & \multirow{2}{*}{2.208} & \multirow{2}{*}{4.875} & \multirow{2}{*}{1.355} & \\
\hline proses $\left(\mathrm{X}_{6}\right)$ & & & & \\
\hline $\mathrm{y}_{1}$ & 0.502 & 0.252 & 0.748 & \\
\hline $\mathrm{y}_{2}$ & 0.775 & 0.601 & 0.399 & \\
\hline y3 & 0.844 & 0.712 & 0.288 & 0.758 \\
\hline Kinerja & \multirow{2}{*}{2.121} & \multirow{2}{*}{4.499} & \multirow{2}{*}{1.435} & \\
\hline $\operatorname{karyawan}(\mathrm{Y})$ & & & & \\
\hline
\end{tabular}

Hasil Pengujian Validitas dan Reliabilitas Instrumen Berdasarkan Confirmantory Factor Analysis(CFA)

Sumber: Data primer diola

Berdasarkan tabel di atas dapat diketahui bahwa:

(1) Nilai loading factor pada semua indikator lebih besar dari $0,50(\lambda>$ $0,50)$, sehingga dapat disimpulkan bahwa indikator yang digunakan dalam mengukur variabel penelitian ini adalah valid, (2) Instrumen yang digunakan dalam pengumpulan data mempunyai tingkat reliabilitas yang tinggi. Hal ini dapat dilihat dari nilai 
construct reliability (CR) setiap variabel lebih besar dari nilai yang dipersyaratkan $(\mathrm{CR}>0,60)$.

\section{Metode Analisis}

Metode analisis data yang digunakan dalam mencapai tujuan penelitian ini, yaitu: (1) Analisis Statistik Deskriptif; dan (2) Structural Equation Modeling (SEM). Analisis statistik deskriptif diguna-kan untuk menggambarkan karakterisitk responden, dan variabel penelitian dengan menggunakan nilai persentase $(\%)$, dan rata-rata (mean). Sedangkan analisis SEM digunakan untuk menguji dan menganalisis pengaruh variabel eksogen terhadap variabel endogen dalam model penelitian, sekaligus memeriksa validitas dan reliabilitas instrumen penelitian secara keseluruhan. Adapun pengolahan data menggunakan bantuan software SPSS dan AMOS Versi 16.00.

Pada saat seorang peneliti menghadapi per-tanyaan penelitian berupa identifikasi dimensi-dimensi sebuah konsep atau konstruk, dan pada saat yang bersamaan ingin mengukur pengaruh atau derajat hubungan antar variabel yang telah diidentifikasi dimensi-dimensinya, maka analisis SEM harus digunakan. Analisis SEM juga merupakan suatu pendekatan terintegrasi antara analisis faktor, model struktural dan analisis jalur (Solimun, 2008). Suatu model dikatakan fit (baik) dalam penggunaan analisis SEM, apabila memenuhi persyaratan-persyaratan sebagaimana disajikan pada Tabel berikut.

Tabel 2.

Indeks Goodness of Fit untuk Evaluasi

Model

\begin{tabular}{|l|c|}
\hline \multicolumn{1}{|c|}{ Goodness of Fit Index } & Cut off Value \\
\hline Chi square & Diharapkan kecil \\
\hline Significance Probability & $\geq 0,05$ \\
\hline RMSEA & $\leq 0,08$ \\
\hline GFI & $\geq 0,90$ \\
\hline AGFI & $\geq 0,90$ \\
\hline CMIN/DF & $\leq 2,00$ \\
\hline
\end{tabular}

\begin{tabular}{|l|l|}
\hline TLI & $\geq 0,95$ \\
\hline CFI & $\geq 0,95$ \\
\hline Sumber: Hair, et al. & $(1998)$.
\end{tabular}

Sumber: Hair, et al. (1998);

Ferdinand, (2006); Solimun (2008)

Pengujian hipotesis dalam analisis SEM dilakukan dengan membandingkan nilai probabilitas/ signifikansi (p) dengan $\alpha=0,05$. Apabila nilai probabilitas / signifikansi hitung lebih kecil dari $\alpha$, maka hipotesis dapat diterima. Sebaliknya, apabila nilai probabilitas / signifikansi (p) lebih besar dari $\alpha$, maka hipotesis ditolak.

\section{HASIL PENELITIAN DAN PEMBAHASAN}

Pada bagian ini diuraikan secara lengkap hasil penelitian yang terdiri atas gambaran karakteristik responden, karakteristik variabel, dan hasil pengujian hipotesis. Kemudian berdasarkan hasil tersebut dilakukan pembahasan terhadap hubungan atau pengaruh yang terjalin diantara variabel yang diteliti. Adapun hasil analisis deskriptif yang menggambarkan karakteristik responden berdasarkan jenis kelamin, usia, tingkat pendidikan, dan masa kerja secara lengkap disajikan pada Tabel 3.

Dari hasil analisis deskriptif diperoleh informasi bahwa responden penelitian ini dominan dengan jenis kelamin laki-laki, yakni sebesar 195 orang $(72,22 \%)$ dan sisanya adalah perempuan sebesar 75 orang $(27,78 \%)$. Dilihat dari segi usia, responden penelitian ini dominan berada dalam kategori usia produktif, yaitu 31-40 tahun $(66,77 \%)$ dan $20-30$ tahun $(17,78 \%)$, sisanya berada pada usia 41-50 tahun $(8,89 \%)$, di atas 50 tahun $(4,81 \%)$ dan di di bawah 20 tahun $(1,85 \%)$.

Tabel 3.

Deskripsi Responden Berdasarkan Jenis Kelamin, Usia, Tingkat Pendidikan dan Masa Kerja

\begin{tabular}{|c|c|c|c|}
\hline No. & Uraian & Frekuensi & Persentase \\
\hline & & (Orang) & $(\boldsymbol{\%})$ \\
\hline I & Jenis Kelamin : & & \\
\hline & - Laki-laki & 195 & 72,22 \\
\hline
\end{tabular}




\begin{tabular}{|c|c|c|c|}
\hline & - Perempuan & 75 & 27,78 \\
\hline & Total & 270 & 100,00 \\
\hline \multicolumn{4}{|c|}{ Usia/Umur (tahun) : } \\
\hline & - di bawah 20 & 5 & 1,85 \\
\hline & $-20-30$ & 48 & 17,78 \\
\hline & $-31-40$ & 180 & 66,67 \\
\hline & $-41-50$ & 24 & 8,89 \\
\hline & - di atas 50 & 13 & 4,81 \\
\hline & Total & 270 & 100,00 \\
\hline III. & \multicolumn{3}{|c|}{ Tingkat Pendidikan : } \\
\hline & - SMA/sederajat & 15 & 5,56 \\
\hline & - Diploma & 152 & 56,30 \\
\hline & - Sarjana (S1) & 95 & 35,39 \\
\hline & - Magister (S2) & 8 & 2,96 \\
\hline & Total & 270 & 100,00 \\
\hline \multicolumn{4}{|c|}{$\begin{array}{l}\text { IV. Masa Kerja } \\
\text { (tahun): }\end{array}$} \\
\hline & - di bawah 5 & 11 & 4,07 \\
\hline & $-5-10$ & 68 & 25,19 \\
\hline & $-11-15$ & 95 & 35,19 \\
\hline & $-16-20$ & 75 & 27,78 \\
\hline & - di atas 20 & 21 & 7,78 \\
\hline & Total & 270 & 100,00 \\
\hline
\end{tabular}

Sumber: Data primer diolah

Tingkat pendidikan responden dominan berada pada tingkat Diploma yakni sebesar 152 orang $(56,3 \%)$, dan sisanya berada pada tingkat Sarjana/S1 sebanyak 95 orang $(35,39 \%)$, SMA/sederajat $(5,56 \%)$ dan Magister sebanyak 8 orang $(2,96 \%)$. Menurut masa kerja, responden dominan memiliki masa kerja antara 5 sampai 20 tahun yakni 238 orang (78\%), sisanya adalah responden yang memiliki masa kerja di bawah 5 tahun (4,07\%), dan di atas 20 tahun $(7,78 \%)$. Selanjutnya dapat diketahui pula bahwa ber-dasarkan nilai rata-rata (mean), variabel total quality management (TQM) telah dilaksanakan secara baik dalam perusahaan. Secara berurutan nilai rata-rata tanggapan responden terhadap variabel TQM adalah: kepemimpinan $(4,33)$; perencanaan strategis $(3,85)$; fokus pada pelanggan $(4,02)$; informasi dan analisis; $(3,63)$; manajemen sumber daya manusia $(4,11)$; dan manajemen proses $(3,77)$.

Pengujian hipotesis untuk menghasilkan suatu model yang fit menggunakan analisis Structural Equation Modelling (SEM). Dengan menggunakan bantuan perangkat lunak Amos 16.00 diperoleh hasil perhitungan goodness-of-fit indices (GFI) atas model lengkap yang menggambarkan jalinan sinergis antar masing-masing variabel penelitian sebagaimana disajikan pada Tabel 4 .

Tabel 4.

Hasil Pengujian Goodness of Fit Overall Model

\begin{tabular}{|c|c|c|c|}
\hline Kriteria & & Hasil & Keteranga \\
\hline Goodness of Fit Index & Cut-off Value & Model & $\mathrm{n}$ \\
\hline Chi square & $\begin{array}{c}\text { Diharapkan } \\
\text { kecil }\end{array}$ & 49,130 & Marginal \\
\hline Significance Probability & $\geq 0,05$ & 0,440 & Baik \\
\hline RMSEA & $\leq 0,08$ & 0,005 & Baik \\
\hline$G F I$ & $\geq 0,90$ & 0,933 & Baik \\
\hline$C M I N / D F$ & $\leq 2,00$ & 1,824 & Baik \\
\hline$T L I$ & $\geq 0,95$ & 0,973 & Baik \\
\hline$C F I$ & $\geq 0,95$ & 0,998 & Baik \\
\hline
\end{tabular}

Sumber: Data primer diolah

Hasil pengujian model pada Tabel di atas, menunjukkan bahwa hampir semua kriteria indeks kesesuaian model telah dipenuhi. Karena itu, model ini telah diterima dengan baik dan selanjutnya dapat digunakan untuk melakukan estimasi terhadap variabel-variabel yang diuji hubungannya dalam penelitian ini.

Berdasarkan model konseptual yang telah dibangun, maka pengujian hipotesis penelitian dilakukan melalui pengujian koefisien struktur persamaan model kausalita penelitian. Adapun hasil pengujian dengan menggunakan structural equation modeling (SEM) secara lengkap disajikan pada Gambar 1 dan Tabel 5. 


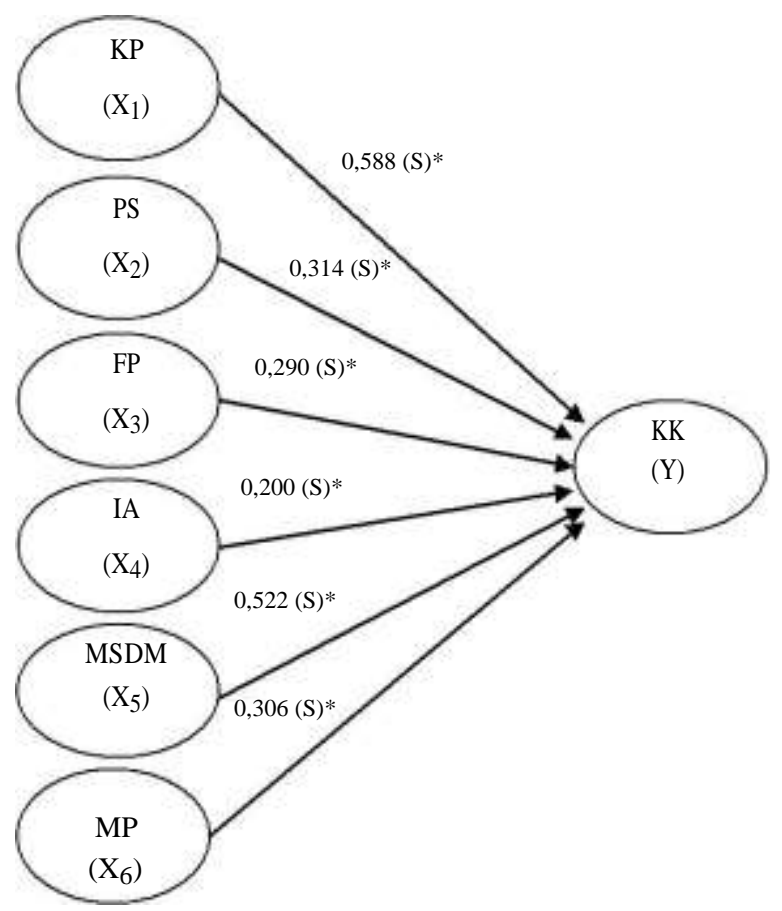

Gambar 1.

Model Struktural Pengaruh praktik TQM Terhadap Kinerja Karyawan

Keterangan: *) Hubungan dan Pengaruh antar variabel signifikan; KP $=$ Kepemimpinan (leadership); PS = Perencanaan strategis (strategic planning); FP = Fokus pada pelanggan (customer focus); IA = Informasi dan analisis (information and analysis); MSDM = Manajemen sumber daya manusia (people management); $\mathrm{MP}=$ Manajemen proses (process management); dan $\mathrm{KK}=$ Kinerja karyawan (employee performance).

\section{Tabel 5.}

\section{Hasil Koefisien Jalur (standardized} regressi-on estimates)

\begin{tabular}{|l|c|c|c|c|c||}
\hline \multirow{2}{*}{ Variabel } & Standar- & & & & \\
\cline { 2 - 6 } & dized & S.E & C.R & P & Ket. \\
\hline & Regression & & & & \\
\hline Kinerja Karyawan (KK) & 0,588 & 0,156 & 7,133 & $0,000 *$ & Signifikan \\
\hline$\leftarrow$ Kepemimpinan $(\mathrm{KP})$ & & & & & \\
\hline Kinerja Karyawan $(\mathrm{KK})$ & 0,314 & 0,147 & 4,344 & $0,005 *$ & Signifikan \\
\hline$\leftarrow$ Perencanaan strategis & & & & & \\
\hline (PS) & & & & & \\
\hline Kinerja Karyawan (KK) & 0,290 & 0,193 & 3,775 & $0,011 *$ & Signifikan \\
\hline$\leftarrow$ Fokus pada pelanggan & & & & & \\
\hline
\end{tabular}

\begin{tabular}{|c|c|c|c|c|c|}
\hline \multicolumn{6}{|l|}{ (FP) } \\
\hline Kinerja Karyawan (KK) & 0,200 & 0,206 & 2,880 & $0,035^{*}$ & Signifikan \\
\hline \multicolumn{6}{|l|}{\begin{tabular}{|l} 
Informasi dan analisis \\
(IA)
\end{tabular}} \\
\hline (IA) & & & & & \\
\hline Kinerja Karyawan (KK) & 0,522 & 0,128 & 6,244 & $0,000^{*}$ & Signifikan \\
\hline \multicolumn{6}{|l|}{ \&Manajemen sumber } \\
\hline \multicolumn{6}{|l|}{ daya manusia (MSDM) } \\
\hline Kinerja Karyawan (KK) & 0,306 & 0,430 & 4,122 & $0,008^{*}$ & Signifikan \\
\hline \multicolumn{6}{|l|}{$\leftarrow$ Manajemen proses } \\
\hline (MP) & & & & & \\
\hline
\end{tabular}

Sumber: Data primer diolah

*) signifikan pada $\alpha=0,05$.

Hasil pada tabel diatas menunjukkan hubungan dan pengaruh yang terjadi antar variabel dalam model penelitian. Berdasarkan hasil pengujian hipotesis, dapat diketahui:

1) Sesuai dengan nilai critical ratio (C.R) dan probabilitas (P), dapat diketahui bahwa variabel kepemimpinan mempunyai pengaruh yang positif dan signifikan terhadap kinerja karyawan. Dimana nilai CR lebih besar daripada nilai yang disyaratkan sebesar $1,960(7,133>$ 1,960), serta nilai probabilitas lebih kecil daripada $\alpha=0,05(0,000<$ $0,05)$. Karena itu, hipotesis I yang diajukan dalam penelitian ini terbukti atau didukung oleh fakta empiris.

2) Sesuai dengan nilai critical ratio (C.R) dan probabilitas (P), dapat diketahui bahwa variabel perencanaan strategis mempunyai pengaruh yang positif dan signifikan terhadap kinerja karyawan. Dimana nilai CR lebih besar daripada nilai yang disyaratkan sebesar 1,960 (4,344 > $1,960)$, serta nilai probabilitas lebih kecil daripada $\alpha=0,05(0,005<$ $0,05)$. Karena itu, hipotesis II yang diajukan dalam penelitian ini terbukti atau didukung oleh fakta empiris.

3) Sesuai dengan nilai critical ratio (C.R) dan probabilitas (P), dapat diketahui bahwa variabel fokus pada pelanggan mempunyai pengaruh yang positif dan 
signifikan terhadap kinerja karyawan. Dimana nilai CR lebih besar daripada nilai yang disyaratkan sebesar $1,960(3,775>$ $1,960)$, serta nilai probabilitas lebih kecil daripada $\alpha=0,05(0,011<$ $0,05)$. Karena itu, hipotesis III yang diajukan dalam penelitian ini terbukti atau didukung oleh fakta empiris.

4) Sesuai dengan nilai critical ratio (C.R) dan probabilitas (P), dapat diketahui bahwa variabel informasi dan analisis mempunyai pengaruh yang positif dan signifikan terhadap kinerja karyawan. Dimana nilai CR lebih besar daripada nilai yang disyaratkan sebesar 1,960 (2,880 > $1,960)$, serta nilai probabilitas lebih kecil daripada $\alpha=0,05(0,035<$ $0,05)$. Karena itu, hipotesis IV yang diajukan dalam penelitian ini terbukti atau didukung oleh fakta empiris.

5) Sesuai dengan nilai critical ratio (C.R) dan probabilitas (P), dapat diketahui bahwa variabel manajemen orang-orang (people management) mempunyai pengaruh yang positif dan signifikan terhadap kinerja karyawan. Dimana nilai CR lebih besar daripada nilai yang disyaratkan sebesar 1,960 (6,244 > $1,960)$, serta nilai probabilitas lebih kecil daripada $\alpha=0,05(0,000<$ $0,05)$. Karena itu, hipotesis $\mathrm{V}$ yang diajukan dalam penelitian ini terbukti atau didukung oleh fakta empiris.

6) Sesuai dengan nilai critical ratio (C.R) dan probabilitas (P), dapat diketahui bahwa variabel manajemen proses mempunyai pengaruh yang positif dan signifikan terhadap kinerja karyawan. Dimana nilai CR lebih besar daripada nilai yang disyaratkan sebesar 1,960 (4,122 >
1,960), serta nilai probabilitas lebih kecil daripada $\alpha=0,05(0,008<$ $0,05)$. Karena itu, hipotesis VI yang diajukan dalam penelitian ini terbukti atau didukung oleh fakta empiris.

\section{Pengaruh Kepemimpinan (leadership) Terhadap Kinerja Karyawan}

Berdasarkan hasil pengujian hipotesis dapat diketahui bahwa nilai Standardized Regression/ loading factor variabel kepemimpinan $\left(\mathrm{X}_{1}\right)$ adalah positif dan signifikan sebesar 0,588 terhadap kinerja karyawan (Y). Hal ini berarti bahwa semakin kuat komitmen yang ditunjukkan oleh manajemen dalam implementasi TQM maka semakin meningkat kinerja yang dicapai oleh karyawan. Variabel kepemimpinan mempunyai pengaruh yang positif dan signifikan terhadap kinerja karyawan dengan kontribusi sebesar $58,8 \%$. Hasil penelitian ini mendukung pendapat bahwa komitmen manajemen yang kuat mampu mendorong meningkatnya kinerja mutu dan kinerja perusahaan (Prayogo and Brown 2004, Prayogo and Dermott 2005). Komitmen manajemen sangat diperlukan dalam mendukung suksesnya imple-mentasi TQM. Karena hal tersebut secara langsung dapat meningkatkan kinerja karyawan, kinerja inovasi, dan kinerja bisnis perusahaan (Zehir and Esin, 2009).

\section{Pengaruh Perencanaan Strategis (strategic planning) Terhadap Kinerja Karyawan}

Berdasarkan hasil pengujian hipotesis dapat diketahui bahwa nilai Standardized Regression/ loading factor variabel perencanaan strategis (X2) adalah positif dan signifikan sebesar 0,314 terhadap kinerja karyawan (Y). Hal ini berarti bahwa semakin baik aktivitas perencanaan yang dilakuan oleh manajemen dalam 
kaitannya dengan implementasi praktik-praktik TQM maka semakin meningkat kinerja yang dicapai oleh karyawan. Variabel perencanaan strategis mempunyai pengaruh yang positif dan signifikan terhadap kinerja karyawan dengan kontribusi sebesar $31,4 \%$.

Perencanaan strategis dalam organisasi per-usahaan mutlak diperlukan sebagai acuan dasar manajemen dalam membuat programprogram dan mengendalikan aktivitas yang dijalankan perusahaan, khususnya berkaitan dengan manajemen mutu. Program-program yang berkaitan dengan peningkatan kinerja, baik kinerja karyawan maupun kinerja perusahaan secara keseluruhan dapat lebih terarah dan dapat diukur secara tepat, apabila suatu organisasi/ perusahaan mempunyai dokumen perencanaan yang sifatnya strategis (Heizer and Render, 2004; Krajewski and Ritzman, 2006).

\section{Pengaruh Fokus Pada Pelanggan (customer focus) Terhadap Kinerja Karyawan}

Berdasarkan hasil pengujian hipotesis dapat diketahui bahwa nilai Standardized Regression/ loading factor variabel fokus pada pelanggan (X3) adalah positif dan signifikan sebesar 0,290 terhadap kinerja karyawan (Y). Hal ini berarti bahwa perusahaan yang semakin fokus dalam melayani pelanggan mampu mendorong pada semakin meningkatnya kinerja yang dicapai oleh karyawan. Variabel fokus pada pelanggan mempunyai pengaruh yang positif dan signifikan terhadap kinerja karyawan dengan kontribusi sebesar $29 \%$. Fokus pada konsumen merupakan salah satu faktor mikro dari dalam perusahaan yang mempengaruhi perubahan dan pengembangan kinerja suatu organisasi, juga sebagai salah satu variabel yang secara signifikan mempengaruhi kinerja karyawan dan kinerja bisnis (Demirbag et al., 2006; Prayogo and Hong, 2008). Hasil penelitian ini mendukung pendapat bahwa fokus pada konsumen merupakan salah satu elemen kunci keberhasilan implementasi TQM (Prayogo and Brown, 2004; Prayogo and Dermott 2005, dan Prayogo and Hong, 2008).

\section{Pengaruh Informasi dan Analisis (information and analysis) Terhadap Kinerja Karyawan}

Berdasarkan hasil pengujian hipotesis dapat diketahui bahwa nilai Standardized Regression/ loading factor variabel informasi dan analisis $\left(\mathrm{X}_{4}\right)$ adalah positif dan signifikan sebesar 0,2 terhadap kinerja karyawan (Y). Hal ini berarti bahwa semakin tersedia data dan informasi serta analisis dalam organisasi maka semakin meningkat kinerja yang dicapai oleh karyawan. Variabel informasi dan analisis mempunyai pengaruh yang positif dan signifikan terhadap kinerja karyawan dengan kontribusi sebesar $20 \%$.

Hasil penelitian tersebut mendukung pendapat bahwa informasi dan analisis dengan bantuan piranti (tools) statistik merupakan salah satu elemen kunci keberhasilan implementasi TQM (Heizer and Render 2004; Chase et al., 2005; Krajewski and Ritzman, 2006). Penggunaan piranti statistik sangat penting dalam membantu proses perbaikan mutu yang berkelanjutan. Manajemen dan karyawan memanfaatkan piranti statistik sebagai bentuk keterlibatan dan kontribusinya dalam praktik TQM. Keterlibatan manajemen dan karyawan secara penuh merupakan wujud dari kesadaran anggota organisasi perusahaan terhadap kualitas. Data dan informasi yang tersedia setiap saat dapat digunakan manajemen untuk melakukan pengawasan terhadap aktivitas produksi. Adanya peningkatan 
keterampilan atau skill karyawan dalam mengelola data dan informasi secara lebih baik berdampak pada kinerja karyawan yang semakin meningkat, khususnya dalam menyediakan data dan informasi bagi pengambilan keputusan manajemen (Prayogo and Brown, 2004; dan Handoko, 2006).

\section{Pengaruh Manajemen Sumber Daya Manusia (people management) Terhadap Kinerja Karyawan}

Berdasarkan hasil pengujian hipotesis dapat diketahui bahwa nilai Standardized Regression/ loading factor variabel manajemen sumber daya manusia $\left(\mathrm{X}_{5}\right)$ adalah positif dan signifikan sebesar 0,522 terhadap kinerja karyawan (Y). Hal ini berarti bahwa semakin efektif pengelolaan sumber daya manusia dalam organisasi maka semakin meningkat kinerja yang dicapai oleh karyawan. Variabel manajemen sumber daya manusia mempunyai pengaruh yang positif dan signifikan terhadap kinerja karyawan dengan kontribusi sebesar 52,2\%.

Beberapa bentuk upaya pemberdayaan karya-wan oleh perusahaan, diantaranya adalah: dibentuk-nya kelompok kerja atau Gugus Kendali Mutu (GKM), pertemuan berkala, aktivitas sumbang saran (brain storming), pengakuan dan penghargaan atas prestasi karyawan di bidang perbaikan dan peningkatan kualitas. Aktivitas pemberdayaan karya-wan berkaitan dengan implementasi TQM secara efektif mampu mendorong meningkatnya kinerja karyawan (Zehir and Esin, 2009).

Hasil penelitian ini juga mendukung pendapat bahwa pemberdayaan karyawan yang diikuti dengan keterlibatan karyawan secara total merupakan salah satu elemen kunci keberhasilan implementasi TQM dalam organisasi (Prayogo and Brown, 2004; dan Krajewski and Ritzman,
2006). Pada saat karyawan diberi wewenang oleh manajemen untuk melakukan pekerjaannya secara otonomi, maka hal tersebut dapat menimbulkan perasaan dihargai dan dipercaya bagi karyawan. Sehingga, hal ini dapat berimplikasi pada meningkatnya semangat, motivasi, dan kinerja karyawan (Handoko, 2006).

\section{Pengaruh Manajemen Proses (process management) Terhadap Kinerja Karyawan}

Berdasarkan hasil pengujian hipotesis dapat diketahui bahwa nilai Standardized Regression/ loading factor variabel manajemen proses $\left(\mathrm{X}_{6}\right)$ adalah positif dan signifikan sebesar 0,306 terhadap kinerja karyawan (Y). Hal ini berarti bahwa semakin efektif pengelolaan proses operasi/produksi dalam organisasi maka semakin meningkat kinerja yang dicapai oleh karyawan. Variabel manajemen proses mempunyai pengaruh yang positif dan signifikan terhadap kinerja karyawan dengan kontribusi sebesar 30,6\%.

Hasil penelitian ini mendukung pendapat bahwa manajemen proses merupakan salah satu elemen TQM yang mempengaruhi kinerja karyawan dan kinerja perusahaan secara keseluruhan. Kinerja karyawan merupakan salah satu dimensi dari kinerja bisnis (Prayogo and Brown 2004, Zehir and Esin 2009). Proses operasi perusahaan yang telah dibakukan dalam standart operating procedures (SOP), merupakan pedoman kegiatan yang harus dijalankan secara konsisten bagi seluruh anggota organisasi. Pengawasan yang dilakukan oleh pihak manajemen terhadap keseluruhan operasi perusahaan secara intensif dapat mengurangi tingkat kesalahan dalam proses operasi, meningkatkan disiplin, dan produktivitas kerja karyawan (Chase et al., 2005). Manajemen proses merupakan salah 
satu elemen penting dari praktik TQM dalam organisasi perusahaan. Proses operasi/produksi yang dikelola secara baik mempunyai banyak manfaat bagi perusahaan, misalnya: adanya keteraturan dalam penjadwalan produksi, pembagian kerja, dan efektifitas dalam pengendalian mutu (Krajewski and Ritzman, 2006).

\section{KESIMPULAN DAN SARAN Kesimpulan}

Berdasarkan hasil penelitian dan pembahasan yang telah diuraikan, maka dapat disimpulkan bahwa variabel-variabel praktik TQM yang terdiri atas (1) kepemimpinan; (2) perencanaan strategis; (3) fokus pada pelanggan; (4) informasi dan analisis; (5) manajemen sumber daya manusia; dan (6) manajemen proses mempunyai pengaruh positif dan signifikan terhadap kinerja karyawan di PT. Bumi Menara Internusa Surabaya. Hal ini merupakan indikasi bahwa derajat meningkat atau menurunnya kinerja karyawan sangat ditentukan oleh variabel-variabel TQM tersebut.

Faktor kepemimpinan (leadership) manajemen yang diwujudkan dalam bentuk dukungan yang kuat adalah sangat penting bagi keberhasilan implementasi praktik TQM. Konsistensi dalam hal keterlibatan secara total manajemen dan karyawan sangat diperlukan dalam aktivitas manajemen mutu. Sehingga praktik TQM yang efektif disamping mampu meningkatkan kinerja karyawan, juga dapat mendorong perusahaan untuk menyediakan produk yang berkualitas dibanding pesaing.

\section{Saran}

Manajemen perusahaan pada PT. Bumi Menara Internusa Surabaya hendaknya mampu membuat kebijakan dan program secara lebih efektif dalam meningkatkan kinerja karyawan berdasarkan variabel praktik total quality management (TQM). Praktik
TQM dapat dilakukan menurut skala priotitas berdasarkan kapasitas dan kapabilitas yang dimiliki perusahaan. Variabel TQM yang masih kurang optimal pelaksanaannya dalam perusahaan hendak-nya menjadi prioritas perhatian bagi manajemen, agar kinerja perusahaan dapat ditingkatkan melalui kinerja karyawan yang semakin baik. Penggunaan piranti statistik sebagai bagian dari alat praktik TQM hendaknya lebih dioptimalkan pemanfaatannya agar data dan informasi mutu dapat diakses dan digunakan secara luas oleh manajemen dalam mengelola kualitas. Kemudian program-program pemberdayaan karyawan juga hendaknya direncanakan dan dijalankan dengan sebaik-baiknya dengan dukungan manajemen secara penuh dalam organisasi perusahaan.

Penelitian ini masih menunjukkan beberapa kelemahan, misalnya obyek penelitian hanya pada satu perusahaan. Sehingga, hasil penelitian ini tidak dapat digeneralisasi pada semua perusahaan. Karena itu, penelitian mendatang dapat mengembangkan penelitian ini dengan menambahkan jumlah perusahaan sebagai unit analisis, dan variabel yang tidak diuji dalam penelitian ini.

\section{DAFTAR PUSTAKA}

Brah, S. and Lim, H. 2006. The effects of technology and TQM on the performance of logistics companies", International Journal of Physical Distribution \& Logistics Management, Vol. 36, No. 3, pp. 192-209.

Chase, Richard B., Nicholas J. Aquilano, F. Robert Jacobs, 2005. Operation Management for Competitive Advantage, Eleventh Edition, McGraw-Hill Inc. USA.

Demirbag, M., Tatoglu, E., Tekinkus, 
M. and Zaim, S. 2006. An analysis of the relationship between TQM implementation and organizational performance: evidence from Turkish SMEs, Journal of Manufacturing Technology Management, Vol. 17, No. 6, pp. 829-47.

Ferdinand, Augusty. 2006. Structural

Equation Modeling dalam Penelitian Manajemen, Universitas Diponegoro, Semarang Indonesia.

Gaspersz, V. 2005. Total Quality

Management. PT. Gramedia

Pustaka Umum, Jakarta.

Hair Jr., Yoseph F., Rolph E. Anderson, Ronald L. Papham, William $\quad$ Black. 1998. Multivariate Data Analysis, $5^{\text {th }}$ edition, Prentice-Hall, Inc., New Jersey.

Handoko, Hani T. 2006. Manajemen Personalia dan Sumber Daya Manusia, BPFE-Yogyakarta.

https://www.ptbmi.com/index/

Juran, J.M. 1989. Juran on Leadership for Quality, The Free Press, MacMillan Inc. E. Nugroho (penterjemah).

1995.

Kepemimpinan Mutu. Pustaka Binaman Pressindo, Jakarta.

Krajewski, J. Lee and P. R. Larry, 2006, Operations Management Strategy and Analysis, Fifth Edition, Addison-Wesley Publising Company Inc.

Lawrence M. Corbett and Kate N. Rastrick, 2000. Quality performance and organizational culture: A New Zealand study,
International Journal of Quality \& Reliability Management, Vol. 17, No. 1, pp. 14-26.

Prajogo, Daniel. I., and Brown, A. 2004. "The Relationship Between TQM Practice and Quality Performance and the Role of Formal TQM Programs: An Australian Empirical Study". Quality Management Journal. 11 (4), pp. 31-42.

Prajogo, Daniel I., and Christopher M. McDermott, 2005. The relationship between total quality Management practices and organizational culture, International Journal of Operations \& Production Management, Vol. 25, No. 1, pp. 1101-1122.

Prajogo, Daniel I., and Soon W. Hong. 2008. The effect of TQM on performance in $R \& D$ environments: A perspective from South Korean firms, Technovation 28, pp. 855-863.

Render, Barry and Jay Heizer. 2004. Operations Management, International Edition, Pearson Education Inc. Upper Saddle River, New Jersey.

Sila, I. 2007. Examining the effects of contextual faktors on TQM and performance through the lens of organizational theory: an empirical study, Journal of Operations Management, Vol. 25, No. 1, pp. 83-109.

Solimun. 2008. Modul Metode Kuantitatif untuk Manajemen, Materi Program Doktor Manajemen. Pascasarjana Universitas Brawijaya Malang.

Sugiyono. 2008. Statistik Untuk Penelitian, Penerbit Alfabeta, 
Bandung, Indonesia.

Tjiptono, Fandy dan Anastasia Diana.

2003. Total Quality

Management, Edisi Ke-4,

Penerbit Andi, Yogyakarta.

Zehir, Cemal and Esin Sadikoglu.

2009. The relation-ship

between total quality

management (TQM) practices

and organizational

performance: An empirical

investigation, International

Journal of Production

Economics, Vol. 11, No. 3, pp.

140-156. 